\title{
"A social worker first and foremost": The motivation and experiences of recently qualified social workers in posts not requiring social work registration in England.
}

\section{$\underline{\text { Introduction }}$}

Over the last five years, the social work landscape in England has been changing rapidly, in terms of the political and public expectations and perceptions of social work, approaches to qualifying education and training, the regulatory framework, and perhaps for those social workers not working in the statutory sector, the value of their qualification in the context of a changing jobs market. There is some anecdotal evidence to suggest that over this period, in parts of the country at least, Newly Qualified Social Workers (NQSWs) without statutory experience on placement have struggled to find employment in statutory children's social work (Community Care Discussion 13.1.2014), and that opportunities in statutory settings within adult social work have been reducing (CFI 2012:2). Previous research on 'non-traditional' social work placements, and placements inside and outside the statutory sector has suggested that some social work students are making decisions not to pursue careers in the statutory sector at all (Scholar, McLaughlin, McCaughan et al 2014), but see roles in the independent and voluntary sectors as offering more opportunities to carry out 'real social work'. Paradoxically though, in such posts it appears that they may not feel that they can describe themselves as 'social workers'. The introduction of new routes to qualification and developments in post-qualifying requirements suggest that the government's commitment to supporting education and training leading to professional qualification for social work outside the statutory sector may be in doubt.

\section{The Context of the Study}

Social work and social work education in England has been experiencing a particularly intense period of change, not to say turmoil, over the last five years. High profile child care tragedies, particularly that of Baby Peter Connelly (Jones 2014), austerity measures (Jordan \& Drakeford 2012), government ideological preferences (Paton, M 12.11.13) and self-doubt on the part of the profession are arguably among the factors influencing these changes. There has been a particular focus on qualifying social work education (Social Work Reform Board 2010; The College of Social Work 2012), and the perceived shortcomings of NQSWs, especially in children and families social 
work (Narey 2014), where there has also been a problem with the retention of experienced social workers (Research in Practice 2015).

These factors have contributed to the creation of 'fast track' post graduate routes to qualification, Step up to Social Work (Department for Education 2013; Smith, McLenachan et al 2013) and Frontline (MacAlister, Crehand \& Olsen 2012) and Think Ahead (Clifton \& Thorley 2014), and more recently to the introduction of social work 'Teaching Partnerships', formal partnerships between Higher Education Institutions and employers (Research in Practice 2015). Focussing on preparation for statutory social work, these routes have been introduced by the government alongside the reformed degree programmes developed by universities in response to the Social Work Task Force recommendations (Social Work Task Force 2009); and to reductions in the bursary funding provided for students on 'traditional' social work programmes (Department of Health 2012). The fast track routes to qualification for the statutory sector are still relatively new and although evaluations have been published in relation to Step Up to Social Work (Baginsky \& Teague 2013; Smith, McLenachan, Venn et al 2013) no evaluation of Frontline has yet been completed. Nonetheless the government appears to be committed to continuing and developing these employer-led models of social work education. The impact of these new routes on statutory placement availability for current students is as yet unknown, but such students are unlikely to be prioritised, particularly in parts of the country where several of the new approaches are being implemented; and the future of traditional programmes, certainly in present numbers, must be in doubt.

Alongside these changes, the government has supported the development of an Assessed and Supported Year in Employment (ASYE), providing NQSWs with extra support during their first year of employment and requiring them to achieve a satisfactory standard of practice within their first year (Department for Education 2015). Although the ASYE is currently not a requirement for social work registration, there is an expectation that it should normally be started within two years of qualification, although not all employers outside the statutory sector currently offer staff the opportunity to do so (British Association of Social Workers 2015). More recently, 'knowledge and skills statements' for children's and adult social work have been developed to be achieved during the ASYE (DfE 2014; DoH 2015), and arrangements for an accreditation test for children and families social workers have been announced by Isabelle Trowler, England's Chief Social Worker for children and families social work (Schraer 2015). 
At the same time, significant cuts to funding for health and social care services, reductions in the scope of public services and a move towards independent, charitable and private forms of provision (Dickinson, Allen et al 2012) have tended to limit social work in the statutory sector to a focus on safeguarding work. This has been an unwelcome development for some social workers, who fear a narrowing of the scope of social work, and a focus on risk management and bureaucratic processes, and an emphasis on individual responsibility (Jones 2012; Lavalette 2012; Rogowski 2012), with less time to develop relationships and to address or even acknowledge wider issues of inequality and disadvantage and their influence on people's lives, a direction of travel that arguably has been under way for some time (Adams \& Shardlow 2005; Dustin 2007).

\section{Qualified Social Workers in England}

In England, 'Social Worker' has been a title protected by law since 2000, (s.61, Care Standards Act 2000) and in order to call oneself a social worker and practise as such, it is necessary to hold the professional qualification and to register with the regulatory body, initially the General Social Care Council (GSCC), which came into being on 1 October 2001 (GSCC 2012). The GSCC was dissolved in 2012, and its 88,474 registered social workers in England were transferred to the Health and Care Professions Council (HCPC). Registrants join and leave the register throughout the year so that the total number of registered social workers changes month by month. The figures here provide a snapshot of the number of registered social workers over the last four years:

\section{Insert Table One about here}

Information about the employment circumstances of registered social workers in England is not easy to obtain (Moriarty \& Murray 2007; Moriarty, Baginsky \& Manthorpe 2015). In a literature review on roles and issues within the social work profession in England, Moriarty et al (2015) struggled to find the 91,001 registered social workers on the register at the time of their research. They found that figures for 2013 indicated that just over half were employed by Local Authorities, but information about the whereabouts of the other 45,000 or so social workers was not available. It is important to remember that while Local Authorities in England have a number of statutory duties to fulfil in relation to social care, originating in the Local Authority Social Services Act 1970, this legislation did not specify that they must employed qualified social workers to carry out these duties, or in fact mention the social work profession at all (Brayne, Carr \& Goosey 2015:57), although statutory guidance, such as the most recent version of Working Together to Safeguard 
Children, (HM Govt 2015) subsequently set out those tasks that must be undertaken by social workers, specifically certain types of assessment. However, the statutory duties and responsibilities of Local Authorities invariably concern the support needs of vulnerable children or adults, and the complexity of this work has meant that Local Authorities have in practice required the knowledge and expertise of well qualified, skilled and professional workers and are major employers of social workers.

The Department for Education (DfE) publishes figures for children's social workers employed in English Local Authorities each September, along with vacancy and turnover rates, and the Health and Social Care Information Centre ( $\mathrm{HSClC}$ ), national provider of data for health and social care, produces similar information relating to social workers in local authority adult services. The following table sets out the most recent figures from these two sources (DfE 2015; HSCIC 2015). Included here too are figures relating to other employers who have responsibility for statutory functions - the Children and Family Court Advisory and Support Service (Cafcass 2015), which describes itself as the largest single employer of social workers in England; and an estimate of social workers employed in Health settings included in the annual report of the Chief Social Worker for Adults (Department of Health 2014).

Insert Table Two about here

Some 40,000 of the 85,000 or so social workers typically on the register then are either employed outside the statutory sector, are self-employed, or are registered but not currently practising (there is no section of the register for non-practising social workers and no requirement to remove one's name from the register while taking a career break of up to two years) (HCPC n.d.b). Moriarty et al (2015:16) identify other employers advertising roles requiring social work registration, including the National Society for the Prevention of Cruelty to Children (NSPCC), Barnardo's, SSAFA, palliative care services and hospices, organisations providing criminal justice services and employment agencies; to which might be added teaching staff at Higher Education Institutions delivering qualifying programmes. However, the HCPC figures suggest that there must be a considerable number of social workers working in roles not requiring a social work qualification, but which do allow them to meet the requirements for registration. For the purposes of registration, the HCPC defines "practising your profession" as "drawing on your 
professional knowledge and/or skills in the course of your work" (HCPC n.d.b), whether or not your post specifies that a social work qualification is needed.

It is not possible to determine the numbers of social workers employed in particular roles via existing publicly available information, or to discover dates of qualification of social workers employed in particular positions or groups of positions. A recent report by Skills for Care for the Department of Health (Skills for Care 2015:12) gives the number of social work students achieving a registerable social work qualification between 2009 and 2013 as averaging 4535 per year. This report analyses data from the Higher Education Statistics Agency (HESA) and the Destination of Leavers from Higher Education (DLHE), and estimates that 53\% of respondents from the 2011-12 cohort and 58\% from the 2012-13 cohort described themselves as in employment as social workers six months after graduation. They consider this to be a reasonable estimate as the numbers are similar to the numbers of newly qualified social workers (NQSWs) recorded for the same periods by Skills for Care and the DfE (2015:46). For the same cohorts, 27\% and 23\% respectively described themselves as working in a health or social care related role (2015: 44). What is not clear however is how many of this latter group are registered with the HCPC and whether they continue to see themselves as social workers, or aspire to social worker roles inside or outside the statutory sector. The Skills for Care report (2015) finds evidence to suggest that younger graduates and those with undergraduate rather than postgraduate qualifications are more likely to be working in social care related roles, and also concludes that it appears that the supply of trained social workers may be too high. However, the National Council for Voluntary Organisations (NCVO) found that a third of voluntary sector employees $(298,900)$ are employed in social work activities, and that $48 \%$ of all voluntary sector employees have university qualifications, although the nature of those qualifications are not specified (NCVO 2015).

This article explores the experiences of six social workers who have achieved their social work qualification in the last five years, in the midst of the developments described above, and who are working in posts that do not require social work registration, mainly outside the statutory sector. It considers what their experiences tell us about their motivation, aspirations and support needs, and what they might contribute to an understanding of individual and collective social work identity in England at a time of change and uncertainty. 


\section{The Research Study}

This study was planned in two phases, the first being two focus groups of between six and eight participants, to inform the development of an interview schedule for use in the second phase, a maximum of eight individual telephone or face to face interviews.

\section{Ethical considerations}

Ethical approval was obtained from the University of Salford's Research Governance and Ethics Committee. Careful attention was given to ensuring that participants provided informed and continuing consent for participation, at initial expression of interest, and on the day of the group/interview. They were given information about confidentiality and anonymity, about their right to withdraw from the project, and explanations about how their data would be used.

\section{Recruitment}

The study used purposive sampling of recently qualified social workers (RQSWs) employed in posts not requiring social work registration, to identify participants who fulfilled the following inclusion critiera. Participants had to:

1. Be employed in organisations providing social care, social action or social work services in the independent, voluntary or public sector, in a role involving delivery of the service but not requiring social work qualification and registration.

2. Have worked in the organisation in this role for a minimum of six months.

3. Have qualified as a social worker from 2010 onwards, on an undergraduate or postgraduate qualifying programme.

Participants were recruited via existing contacts in services providing social work placements for The University of Salford, who were asked to forward emails publicising the study within their organisations, providing potential participants with information about the study, and inviting them to email the researcher to express interest in taking part. Participants were also invited to pass on details about the study to friends or colleagues meeting the participation criteria.

Regrettably it proved impossible to recruit participants able to attend focus groups on the available dates, and the one session that did run was poorly attended (by only 3 people) and became an informal discussion, which was valuable in identifying some areas for inclusion in the interview schedule. Six RQSWs were recruited for the individual interviews, one of which took place by telephone, and the others either at the participant's place of work or at the University, according to their preference. Of the six:

- 5 were female, 1 male 
- Their qualifications were obtained at 5 different HEls in NW England

- 2 had qualified at Masters level; 4 at undergraduate level

- 4 had studied full-time; 2 part time

- 5 were HCPC registered

- 5 qualified in 2013, one in 2012.

\section{Data Collection}

Individual interviews were semi-structured, with participants asked to talk about five broad areas:

- motivation for qualifying as a social worker; career aims at the beginning and end of their programmes of study, and employment history before and after qualifying

- factual details about their current jobs

- day to day experiences in these roles, including opportunities to use social work skills, knowledge and values and the relevance of their qualification to the role

- views about their social work identity

- future plans and aspirations, with an opportunity at the end of the interview to add any other points

\section{Data Analysis}

Interviews were digitally recorded with the participants' consent, and transcribed in full. The transcripts were read in detail and individual responses to each area of discussion were collated and compared, and examples of agreement and difference were identified. Within each broad topic area the analysis identified as many distinct elements of meaning as possible, following Braun and Clarke's (2006) guidelines for thematic analysis. Because I carried out this study as a sole researcher, it must be acknowledged that the process and outcome of analysis is potentially susceptible to my interests and preconceptions.

\section{The Participants}

All six participants were employed by charities at the time of the study. Four worked for local groups affiliated to two national organizations, and the other two for independent refuges for women leaving abusive relationships. Two participants held two part time (PT) posts, the others were in full time (FT) positions. Four of the participants went directly into employment with their final placement agency on qualifying, and a fifth initially took a job elsewhere, but later secured a full time role at the agency where she had completed final placement. The sixth found employment as a Family Support Worker with a women's refuge, an organisation with which she had no previous connection. 
None of these posts required applicants to hold a social work qualification, although M's role as Senior Project Manager at R1 required a professional qualification, and W's Independent Mental Health Advocate Role (IMHA) with MH1 required an IMHA certificate and two years' relevant experience. As she had relevant experience in her final placement, she was offered the post and is currently undertaking the IMHA certificate. The posts held by the other four participants did not specify any required qualifications, but all participants said that they felt their social work qualification had helped secure their position.

Only the two participants working for $\mathrm{MH} 1$ had immediate work colleagues employed in roles requiring social work qualification (although there were other qualified staff in similar roles to themselves). $\mathrm{K}$ and $\mathrm{O}$ currently work together on a pilot project based in a hospital but otherwise do not have contact with other qualified social workers employed by $O A$, in specific social work posts or otherwise. $\mathrm{K}$ is not aware of any other qualified social workers in his team at $\mathrm{MH} 2 \mathrm{M}$ is the only member of staff with a social work qualification in her organisation, and B has a RQSW colleague in a similar role to hers.

$\mathrm{B}$ at $\mathrm{R} 2$, and $\mathrm{O}$ and $\mathrm{W}$ at $\mathrm{MH} 1$ have been able to undertake the ASYE; $\mathrm{K}, \mathrm{S}$ and $\mathrm{M}$ have all expressed an interest in doing so to their employers but this has not been available.

\section{Findings}

\section{Motivation \& Experience}

The range of factors that motivated participants to train as social workers would be familiar to most social work educators - these included personal experiences as service users; the influence of relatives in similar professions; a desire to work with people in a 'caring' role or to do something they saw as valuable and worthwhile; and for those with experience in the social care sector, a wish to develop their skills, knowledge and ability to make a difference by becoming qualified (Furness 2007; Stevens, Moriarty, Manthorpe et al 2012). One participant acknowledged that she did not have a full understanding of the role at the time of applying, and another saw the qualifying programme as offering a range of career options, not just within statutory social work. By the end of the programme, most said that their career plans had changed as a result of placement experiences. Only one of the six had completed a statutory placement. Because of this two participants said they were not confident that they were ready for a statutory post, and did not expect to be shortlisted by statutory employers. Three participants (including the one who had 
experienced a statutory placement) said that they were not sure that statutory social work was for them, and for the moment at least they intended to remain outside the statutory sector.

\section{Current Roles -Positive Features}

In general, participants were positive about the work they were doing with service users in their current roles, and the opportunities this provided them with to make use of social work skills and methods, and to practise in accordance with social work values. All expressed a sense of commitment to the work they were doing and the service users with whom they were working. The two strongest themes, which all six talked about, were the opportunities they had to 'work alongside service users', and related to this, a sense of autonomy in their work. They compared this to what they had heard from colleagues in the statutory sector who they believed were more subject to restrictions of time, legislation, policy and hierarchical management structures.

There was variation in the depth and complexity of the work undertaken by the RQSWs, depending on the positions they held, but all commented positively about the interesting nature of the work, the degree of autonomy they felt that they had, and the responsibility they had for making decisions (not a particular feature of statutory social work according to Burt \& Worsley 2008:39). This was a strong theme throughout the interviews:

I have so much autonomy over my work. I enjoy it, and I see the value that it brings to people. [W:MH1]

I've got a lot more autonomy, and I make my own decisions. [M:R1]

Some of the interviewees had specific management and/or service development roles. Two had formal responsibility for the supervision of staff (M.R2 and S:OA); and S and $\mathrm{K}$ were employed by OA to develop and pilot a new hospital based project to respond to the social needs of older adults by linking them to services in their local communities. Others mentioned aspects of their work which allowed them to develop skills in management and service development:

I was reading some research about hoarding and we don't do anything about hoarding. I went to my manager and said, I think we could do this that and the other on this, and I have got a meeting this afternoon with someone from another organisation [...] to see what we can put together. [O:MH1] 


\section{Current Roles - Less positive features}

Things were not perfect however, and there were some drawbacks to working in the voluntary sector in roles not requiring qualification. Surprisingly perhaps, none of the participants complained about pay, although several acknowledged that they struggled given that salaries are lower than they would be in statutory social work.

It's difficult to live off what we get, we do have the living wage but it's not... I'm actually on less now that before I was qualified, because I could work more hours and it was a higher rate of pay. [O.MH1]

Despite this, $\mathrm{O}$ said that for the short to medium term she wanted to remain working for $\mathrm{MH}$. She said she would be uncomfortable if she were earning a salary that prevented her from empathising effectively with service users on or below the minimum wage. Another participant said that she was not motivated by money at all. Insecurity and uncertainty about the stability of employment appeared to be a greater concern amongst participants, and some suggested that this sense of precariousness had meant that they had had to compromise their search for their 'ideal' position, whatever that might be:

The funding for [a previous role] came to a sudden end... at the end of the day I would have to find a job doing anything because I have to have work, I've got a mortgage to pay [K:OA]

For most of the participants, lack of contact with and supervision from qualified social workers was experienced as a disadvantage of their posts.

Individual professional identity: Am I a social worker?

It was clear from the participants' accounts of their current roles that they felt that they were able to make use of aspects of their social work training in their work, despite the fact that the qualification was not a requirement of the job. A key question for this study though was whether or not RQSWs in these circumstances regarded themselves as social workers. All were clear that use of the term 'social worker' to describe oneself is dependent on registration with the HCPC, and that this is based on the nature of the work being undertaken rather than on the title of the post one occupies.

In response to the question, 'Do you see yourself as a social worker?' five of the six interview participants responded positively, although there was variation in the strength of their responses, suggested by the speed of their replies and the degree of certainty and conviction they expressed. 
Three participants had no hesitation in confirming their sense of themselves as social workers, although it is perhaps significant that all of these had completed the ASYE:

I do identify myself as a social worker...erm, it fits in with my ethos and my skills and my own personal values. [0:MH1]

Yes, yes I do [...] I suppose it's the fact that I spent all that time working towards it, that yes [...] I still have the knowledge and skills from it that makes me more whole... [W:MH1]

One participant's immediate response was to answer negatively, but to go on to qualify this and then to move through ambivalence to a more positive response:

I wouldn't...in a literal sense...because I'm not...that isn't my job, but in a broader sense see myself as someone who is $\boldsymbol{A}$ social worker, not 'a social worker' as in the job. But I kind of feel like I've been doing similar work without the title, and have been...erm..for a while, but yes, so I kind of...yes and no [K:OA]

One participant, not registered with the HCPC, was uncertain. This was partly because she knew that without HCPC registration it would be unlawful for her to describe herself as a social worker. She agreed that given her current role and responsibilities, registration would be possible for her, in which case she would be able to use the protected title, but she was unsure if this was something she wanted:

...there are certain things that have happened historically with social work that has give it quite a negative connotation, if you like, and I think that's really unfortunate and really unfair actually, but I think the public perception of social work is not a positive one. [S:OA]

All six participants said that they were carrying out social work in their current posts, and compared this to the kind of work they believed their statutory colleagues were undertaking (...you could argue it's more social work than what statutory social workers do [O]) and by referring back to what they had learned about the nature of social work on their qualifying programmes (I think the work I do here is more like what I learnt on the course [M]). They said that they were consciously making use of social work skills and knowledge on a daily basis. However they placed greater emphasis on the particular perspective that social work brought to their work and to their lives, which was linked with the value base of social work. All six participants made reference to this at some point during the interviews:

A lot of the social work values...they become ingrained into part of your personality...I'd struggle to separate it out now... [O:MH1] 
Acknowledgement by family, friends or employers of their social work identity and the value of their professional qualification was another significant factor for four of the participants.

Their responses then suggest that it is not necessary to have 'social worker' in the title of your job, or hold statutory powers in order to see yourself as a social worker, although all were aware that these two factors are often conflated to define social workers in England.

No...I don't...well I do in a way...well I do...because I have...I do use the values and norms, and I do work under HCPC guidelines and things but I've not got any statutory powers [..... But that's the only thing I don't do, I haven't got statutory powers. Erm...no, I am a social worker first and foremost [M:R2]

\section{Collective Professional Identity: What makes someone a social worker?}

Participants were asked to talk about their understanding and conceptualisation of the nature of social work, and to explain what they regarded as core attributes of the profession, and of those who practise it. Given that most of them were working alongside other non-social work qualified staff in the same or very similar roles, what, if anything, distinguished those with the qualification from those without? Here, responses were more varied, and some struggled to articulate their positions and views. Some talked again about the values that they brought to the work.

I think there must be that desire to want to be compassionate towards people and support people, and promote independence, and all those sort of things. At the core those things have to be present, before anything else. [S:OA]

Some talked about social workers in the statutory sector - through internal organisational and external political pressures - having 'lost the essence of social work'; some drew comparisons between the kinds of tasks they were undertaking and those performed by social workers in the statutory sector and concluded that there were few differences, except for the exercise of statutory powers:

I don't know. [Hesitates]. It is just...it's what we are doing I think. [Hesitates] It is, it is exactly what we are doing...now I am talking about it, it does make sense to say we actually are doing exactly the same things that social workers are doing, it's just that we've not got that job title. [B:R2]

Two participants identified that the differences they had noticed between themselves and nonsocial work qualified staff concerned self-awareness, and awareness of the reasons for working in a particular way.

I think that the way that I work...I think...it's a difficult one that, because I think I do 
the things I do because of my background, my work background, and my training. But I think that people that aren't social workers can do it as well, but don't recognise the way that they work. [M.R1]

It's a way that you think about things, that someone who hasn't gone through a social work degree might not. [W:MH1]

A direct question about what they thought their social work qualification had done for them elicited some more specific responses. Although five participants felt that they had not had the practice placements that they would have liked - only one person had experienced a placement in a statutory setting - two (both of whom had had little relevant work experience prior to their courses) commented that the placement element of the course had been invaluable.

I couldn't have done this job without going to uni and doing social work; I didn't have any experience whatsoever. [B:R2]

I definitely found the experience of working on the placement [valuable] on a personal developmental level. [K:OA; $\mathrm{MH} 2]$

All participants talked about what they described as the 'theory' they had learned on their qualifying programmes. There were differences in the examples of theory they provided, some focussing on what might be called practice methods, for example assessment models and specific interventions (Parker \& Bradley 2014) and some including theory from disciplines such as psychology and sociology, or theories contributing to an understanding of social justice, inequalities and oppression. However all were clear that this learning remained relevant and was an important part of what makes a social worker:

I used to think I did things a certain way because of the kind of person that I am, but it's not. It's about the way I've learnt my theories and methods. I understand why I'm doing things a certain way. [M:R1]

Four participants went on to talk about how the academic content had contributed to what they saw as a distinctively social work approach:

We look at it holistically, whereas someone else might just [say], 'Let's go out and address that thing. [W.MH1]

I think my social work helps me think about the bigger picture. [M:R1]

Several talked in general terms about the transformative nature of social work education, and two powerfully expressed the way in which they felt the 'social work perspective' had become part of them:

I kind of really changed how I see things...I do feel like I have had my eyes opened 
and I have done for a few years now. It's incorporated into my world view now. [K:OA;MH2]

You change massively, the way you view life changes. It's as if you've got social work glasses on, and you see things through those. You've been without them for all those years and then you put them on and you have a different view of the world.[W:MH1]

\section{Discussion: Maintaining a social work identity in roles not requiring social work registration}

Overall, the study participants clearly valued their social work education, training and qualification, both for what it brought to them as individuals, and, for most of them, as a professional discipline with the potential to play an important part in the lives of vulnerable individuals, bringing an understanding of the circumstances of those individuals within a wider social and political context. However, running through the interviews were examples of uncertainty and lack of confidence about whether, or for how long, they could legitimately regard themselves as social workers, and for some participants at least, a sense of disconnection from the profession, demonstrated by limited awareness of recent changes and current developments.

A combination of answers to direct questions about what they thought would enable them to continue to see themselves as social workers, and analysis of other elements of the interviews, revealed a number of factors that would support RQSWs in maintaining their identity as social workers, and others that threatened or challenged this. There was a considerable degree of consistency amongst participants about the factors that were important:

Insert Table Four about here

Some of the factors identified as of relevance to social work identity were two sides of the same coin; e.g. contact with other social workers providing support, while lack of contact was seen as a threat. Space does not allow for a detailed discussion of each of these factors here, but in the light of the developments in social work and social work education referred to earlier, there appear to be three themes that capture most of the points made by the study participants, and which I would argue require the attention of the profession if it wishes social work as a professional discipline to maintain a presence in what Lavalette has called 'popular' social work (Lavalette 2012:271) 
Legitimacy

All participants were clear that without HCPC registration they would not be able to refer to themselves as social workers, even with their professional qualification. There was some uncertainty amongst the group as to the relationship between registration and the ASYE. Not having access to or being denied the opportunity to complete the ASYE appeared to contribute to doubts and ambivalence about whether they could consider themselves to be social workers. One participant said she had been relieved when her employer enabled her to complete the year, as she had understood from her university that if she did not do so within two years, 'my qualification would kind of get wiped' [B:R2]. While currently this is not the case, and completion of the ASYE is not a requirement of registration, evidence of continuing professional development (CPD) is, and access to funded training events as well as time for development was not readily available to all participants. One question therefore is for how long qualified social workers in these circumstances will maintain their registration, and whether this matters, beyond the consequence that if they do not, they will not legally be able to refer to themselves as social workers. While there is some research that addresses the relationship between registration and professional identity amongst students (Wiles 2014) there appears to be little or no work exploring the role of registration in supporting professional identity amongst social workers in posts that do not require a social work qualification.

\section{Authenticity}

Beyond the question of legitimacy conferred by certification, regulation, accreditation and similar processes, some of the participants appeared troubled by a feeling that they might not be, or be regarded as, 'real' or authentic social workers, given media and public perceptions tending to equate social work with statutory functions, particularly concerning child welfare. Blewett, Lewis \& Tunstill (2007:4) note that for many years, being a social worker has been synonymous with working for a local authority social services department, and certainly the new approaches to social work education are focused on the delivery of statutory functions, if not statutory employers. There was some ambivalence amongst the participants about describing themselves as social workers to service users in their current roles, some suggesting that they would like to contribute to a more positive and inclusive understanding of the role while others were uncomfortable about possible negative reactions. The now defunct College of Social Work (nd: 5) in the advice note Roles and Functions of Social Workers in England addressed the place of social workers in a range of settings, pointing out that not every 'situation, role or function' is equally 
applicable in all settings, but that there are many circumstances in which social workers are particularly well equipped to act as a lead professional.

\section{Community}

The participants valued contact with other social workers in the course of their work, as colleagues (which appeared to be of particular significance to them) and through contact with social workers employed elsewhere, and informally via friends or family members in the profession. This enabled them to discuss professional issues in general terms and to follow developments in policy, practice and the organisation of service delivery in other parts of the profession. Although all the RQSWs interviewed received organisational supervision from their line managers (except S who said '। would LOVE to have supervision' - but wasn't), none routinely had access to reflective supervision from a qualified social worker. Those who had done the ASYE received reflective supervision from a social worker during the course of that year, and W said that she had recently begun receiving supervision from an external supervisor, a mental health nurse. All said that they would welcome the kind of developmental, social work supervision they had experienced as students. While a review of the research literature on supervision concluded that the evidence for its impact on service users is weak, it was found to have positive benefits on worker satisfaction, self-efficacy and stress (Carpenter, Webb \& Bostock 2013), and Manthorpe et al (2015) cite research by Adamson (2012) suggesting that supervision is important in sustaining professional resilience, as well as having a role in quality assurance. Wenger (1998) discusses the significance of communities of practice, through which individuals share knowledge and experience, to the maintenance of identity, and to personal and professional development. Although most of the participants in the study were not members of the College of Social Work at the time of the interviews, all expressed interest in joining as a way of connecting with other social workers, the loss of this nascent professional association is at the least a setback for the profession (Jones 2012).

\section{Conclusion}

The experiences of this group of RQSWs suggest that there continues to be a role for social work outside the statutory sector, and that there are RQSWs in posts not requiring social work registration who are using their social work skills, knowledge and values to benefit service users and represent the profession. Given that social work is said to be the "key activity of the voluntary sector' (NCVO 2015), the value of staff with a social work qualification, even where this is not 
formally required, may be more significant than is generally acknowledged. Some of the employers represented here recognise and value staff with the qualification, make use of their skills and qualities and support their development; others appear less aware of their potential and how they might contribute to their organisations. However, in the move to develop fast track routes to qualification, the new teaching partnerships, and the introduction of the ASYE and accreditation of children's social workers, little attention appears to have been given to social work outside the statutory sector, or to the consequences for students and RQSWs caught in the transitional period, including the individuals who participated in this study. Some of these have not been able to or perhaps have not wanted to take statutory posts and though registered as social workers have been unable to access ASYE programmes. They are potential ambassadors for social work in a non-statutory context, in whom the state has already invested via bursaries and the Education Support Grant, which supports the practice elements of qualifying programmes. However, in some instances these social workers find themselves isolated, and struggling to maintain a sense of legitimacy and authenticity as professional social workers.

\section{Tables}

Table One: Registered Social Workers by year

\begin{tabular}{|l|l|}
\hline Year & No. of registered SWers \\
\hline May 2015* & 88726 \\
\hline Dec 2014** & 85360 \\
\hline Nov 2013** & 87843 \\
\hline Aug 2012 & 88474 \\
\hline
\end{tabular}

* Source: HCPC (2015)

$* * \quad$ Source: HCPC (n.d.)

Table Two: Employment of Registered Social Workers 2015

\begin{tabular}{|l|l|}
\hline Organisation & Number of social workers \\
\hline Local Authority Children's Services Departments & 26810 \\
\hline Adult Statutory Social Care & 15400 \\
\hline Health Settings & 2000 \\
\hline Cafcass & 1368 \\
\hline Total & 45578 \\
\hline
\end{tabular}


Table Three: Employment status of participants

\begin{tabular}{|c|c|c|c|}
\hline Participant & Current Employer & Job Title & Employment History \\
\hline 0 & $\begin{array}{l}\text { Mental Health Charity } \\
\text { (MH1) }\end{array}$ & Group Facilitator & $\begin{array}{l}\text { Moved straight into this } \\
\text { role on qualifying (final } \\
\text { placement) }\end{array}$ \\
\hline W & $\begin{array}{l}\text { Mental Health Charity } \\
\text { (MH1) }\end{array}$ & $\begin{array}{l}\text { Independent Mental } \\
\text { Health Advocate (\& } \\
\text { Community MH } \\
\text { Advocate (both part } \\
\text { time roles) }\end{array}$ & $\begin{array}{l}\text { Employed in similar role } \\
\text { in final placement agency } \\
\text { on qualifying. Moved } \\
\text { area and took current PT } \\
\text { IMHA post, has recently } \\
\text { begun other PT role. }\end{array}$ \\
\hline K & $\begin{array}{l}\text { Older Adults Charity \& } \\
\text { Mental Health Charity } \\
\text { (OA \& MH2) }\end{array}$ & $\begin{array}{l}\text { Assistant Advice } \\
\text { Manager (OA) and } \\
\text { Telephone Advisor } \\
\text { (MH2) (both part time } \\
\text { roles) }\end{array}$ & $\begin{array}{l}\text { Has had a number of roles } \\
\text { since qualifying and is } \\
\text { currently working in two } \\
\text { part time jobs, one with } \\
\text { final placement agency } \\
\text { (OA) }\end{array}$ \\
\hline$S$ & $\begin{array}{l}\text { Older Adults Charity } \\
\text { (OA) }\end{array}$ & Advice Manager & $\begin{array}{l}\text { Has worked for this } \\
\text { organisation (final } \\
\text { placement) since } \\
\text { qualifying, in different } \\
\text { roles. }\end{array}$ \\
\hline$M$ & $\begin{array}{l}\text { Refuge for women and } \\
\text { children } \\
\text { (R1) }\end{array}$ & Senior Project Manager & $\begin{array}{l}\text { Worked occasional shifts } \\
\text { on qualifying before } \\
\text { taking current post in this } \\
\text { organisation (final } \\
\text { placement) }\end{array}$ \\
\hline B & $\begin{array}{l}\text { Refuge for women and } \\
\text { children } \\
\text { (R2) }\end{array}$ & Family Support Worker & $\begin{array}{l}\text { Has worked in this post } \\
\text { since soon after } \\
\text { qualifying. }\end{array}$ \\
\hline
\end{tabular}


Table Four: Factors supporting and threatening Social Work identity

\begin{tabular}{|l|l|}
\hline \multicolumn{1}{|c|}{ Factors supporting SW identity } & \multicolumn{1}{c|}{ Factors threatening SW identity } \\
\hline HCPC registration & Precarious employment situations \\
\hline Access to the ASYE & Lack of access to the ASYE \\
\hline Employer values their SW qualification & $\begin{array}{l}\text { Lack of access to training \& professional } \\
\text { development }\end{array}$ \\
\hline Access to training \& professional development & $\begin{array}{l}\text { Prevailing discourse equating social work with } \\
\text { statutory functions (esp.child care) }\end{array}$ \\
\hline Having SW students in the organisation & $\begin{array}{l}\text { Lack of confidence in ability to undertake } \\
\text { statutory social work }\end{array}$ \\
\hline Support to become a Practice Educator & Negative public perceptions of social work \\
\hline Contact with other social workers & Lack of contact with other social workers \\
\hline Social Work supervision & Little access to social work supervision \\
\hline Reading 'Community Care' & \\
\hline Sense that they were providing service users & \\
\hline
\end{tabular}

\section{References}

Adams, A., \& Shardlow, S, (2005), The construction of social work in England, in P.Erath, J. Keller, and B. Littlechild, (eds) De- and Reconstruction in European Social Work, Eichstatt: iSiS, 143-158 Anonymous (2012) Child protection job rejections revealed my real social work passion.

Community Care 2.11.12, http://www.communitycare.co.uk/2012/11/02/child-protection-jobrejections-revealed-my-real-social-work-passion/

Baginsky, M, \& Manthorpe, J, (2014), The Views of Step up to Social Work Trainees: Cohort 1 and Cohort 2: Research Report, London: Department for Education https://www.gov.uk/government/uploads/system/uploads/attachment data/file/304903/RR327 - Step up.pdf

Baginsky, M, \& Teague, C, (2013), Speaking from experience: the views of the first cohort of trainees of Step Up to Social Work. Research Report, London: Department for Education 
Berry-Lound, D, \& Rowe, V, (2013), Evaluation of the Implementation of the Assessed and Supported Year in Employment (the ASYE) for Skills for Care: Revised Final Report November 2013, Horsham: HOST Policy Research, http://www.skillsforcare.org.uk/Document-library/NMDS-SC,workforce-intelligence-and-innovation/Research/Concept-to-reality-/ASYE-Final-Report.pdf Blewett, J, Lewis, J, \& Tunstill, J, (2007), The Changing Roles and Tasks of Social Work: A literature informed discussion paper, www.scie.org.uk/news/files/roles.pdf Brayne, H, Carr, H, \& Goosey, D, (2015), Law for Social Workers, 13th edition, Oxford: Oxford University Press.

Braun, V, \& Clarke, V, (2006), Using thematic analysis in psychology.,Qualitative Research in Psychology 3, 1388-1407

British Association of Social Workers, (2015), Assessed and Supported Year of Employment: questions and answers, http://cdn.basw.co.uk/upload/basw 122527-3.pdf British Association of Social Workers,(n.d.)' Advice for newly-qualified social workers: Finding employment, http://cdn.basw.co.uk/upload/basw 105944-9.pdf

Burt, M, \& Worsley, A, (2008), Social work, professionalism and the regulatory framework, in A. Fraser and S. Matthews, (eds) The Critical Practitioner in Social Work and Health Care, London: Sage

CAFCASS, (2015), Freedom of Information Request, https://www.cafcass.gov.uk/media/240957/caf 15-2 cafcass employee statistics.pdf Carpenter, J, Webb, C ,\& Bostock, L, (2013), The surprisingly weak evidence base for supervision: findings from a systematic review of research in child welfare practice (2000-2012), Children and Youth Services Review 35,11, 1843-1853

Carpenter, J, Patsios, D, Wood, M, Platt, D, Haines, C, Wong, C, \& Blewett, J, (2012), Newly Qualified Social Worker Programme: Final evaluation report (2008 to 2011).,Research Report DFERR229 edn, Department for Education: London https://www.gov.uk/government/uploads/system/uploads/attachment_data/file/184032/DFERR229.pdf Centre for Workforce Intelligence, (2012), Workforce Risks and Opportunities Social Workers. https://www.google.co.uk/?gws rd=ssl\#q=www.cfwi.org.uk\%2Fsocial-workers-wro-2012. Clifton, J, \& Thorley, C, (2014), Think Ahead: meeting the workforce challenges in mental health social work, London: Institute for Public Policy Research http://www.ippr.org/files/publications/pdf/ThinkAhead May2014.pdf?noredirect=1 
Community Care Discussion Thread 13.1.2014, Am I unemployable if I finish my social work degree without statutory experience?, http://www.communitycare.co.uk/2014/01/13/discussionthread-unemployable-finish-social-work-degree-without-statutory-experience/

Department for Education,(2013, March 3), Step UP to Social Work: new cohort announced, http://www.education.gov.uk/childrenandyoungpeople/social/becomingasocialworker/b0020099 6/step-up

Department for Education, (2014), Children's social work workforce during year ending 30 September 2014,

https://www.gov.uk/government/uploads/system/uploads/attachment data/file/406660/Childre n_s Social Work Workforce 2013-14_SFR.pdf

Department for Education, (2014), Knowledge and Skills Statement for child and family social work https://www.gov.uk/.../140730_Knowledge_and_skills_statement_final_...

Department for Education, (2015), Policy Paper: Assessed and Supported Year in Employment , https://www.gov.uk/government/publications/assessed-and-supported-year-in-employmentasye/assessed-and-supported-year-in-employment

Department of Health, (2012), New social work bursary details set out , https://www.gov.uk/government/news/new-social-work-bursary-details-set-out Department of Health, (2014), Annual Report by the Chief Social Worker for Adults: One Year On, https://www.gov.uk/government/uploads/system/uploads/attachment data/file/368485/Annual report 2014 web final.pdf

Department of Health, (2015), Knowledge and Skills Statement for Social Workers in Adult Services, https://www.gov.uk/government/uploads/system/uploads/.../KSS.pdf

Dickinson, H, Allen, K, Alcock, P, Macmillan, R, \& Glasby, J, (2012), The Role of the Third Sector in Delivering Social Care, London.:School for Social Care Research. http://www.Ise.ac.uk/LSEHealthAndSocialCare/pdf/SSCR-Scoping-Review 2 web.pdf Dustin, D, (2007), The McDonaldization of Social Work, Farnham: Ashgate Furness, S, (2007), An Enquiry into Students' Motivations to Train as Social Workers in England, Journal of Social Work, 7, 239-253

General Social Care Council, (2012), The GSCC: A 10-year review, http://www.socialworkconnections.org.uk/features/279/the gscc a 10-year review Harris, J, (2008), State Social Work: Constructing the Present from Moments in the Past, The British Journal of Social Work, 38, 4, 662-679 
Health and Social Care Information Centre, (2015), Personal Social Services: Staff of Social Services Departments, England, http://www.hscic.gov.uk/catalogue/PUB16834/pss-staff-eng-14-rpt.pdf HCPC ,(n.d.a), FOI disclosure log, http://www.hpcuk.org/publications/foi/index.asp?startrow=111\&action=step\&sKeyword=\&sCategory=\&sSubCate gory $\mid \mathrm{Ds}=\&$ sAudience $\mid \mathrm{D}=\& \mathrm{sDay} 1=\& \mathrm{sMonth} 1=\& \mathrm{sYear} 1=\& \mathrm{sDay} 2=\& \mathrm{sMonth} 2=\& \mathrm{sYear} 2=$ HCPC , (n.d.b), Leaving the Register http://www.hpc-uk.org/registrants/remove/ HCPC, (n.d.c), Signing your professional declaration, http://www.hpcuk.org/registrants/renew/declaration/ HCPC, (2014), Number of registrants broken down by country and profession, http://www.hpcuk.org/assets/documents/10004B7AStatsallregistants.pdf HCPC, (2015), Social workers in England, http://www.hcpc uk.org.uk/aboutregistration/professions/index.asp?id=18 H.M.Government, (2015), Working Together to Safeguard Children: a guide to interagency working to promote and safeguard the welfare of children, https://www.gov.uk/government/uploads/system/uploads/attachment data/file/419595/Workin

\section{g Together to Safeguard Children.pdf}

Jones, R, (2012), The Best of Times, the Worst of Times: Social Work and Its Moment, British Journal of Social Work 44, 3, 485-502.

Jones, R, (2014), The story of Baby P; setting the record straight, Bristol: Policy Press Jordan, B, \& Drakeford, M, (2012), Social Work and Social Policy under Austerity (Reshaping Social Work), Basingstoke: Palgrave Macmillan Lavalette, M, (2012), Globalisation, austerity and social movements: Whose side are we on? Argumentum, Vitoria (ES), 4,2,259-278

MacAlister, J, Crehand, L, \& Olsen, A, (2012), Frontline: Improving the children's social work profession, London: Institute for Public Policy Research, http://www.ippr.org/publications/frontline-improving-the-childrens-social-work-profession Manthorpe, J, Moriarty J, Hussein, S, Stevens, M, \& Sharpe, E, (2015), Content and Purpose of Supervision in Social Work Practice in England: Views of Newly Qualified Social Workers, British Journal of Social Work, 45,1, 52-68

Moriarty, J, Baginsky, M, \& Manthorpe, J, (2015), Literature review of roles and issues within the social work profession in England, London: Social Care Workforce Research Unit, King's College. http://www.kcl.ac.uk/sspp/policy-institute/scwru/pubs/2015/reports/moriarty-et-al-2015-PSA.pdf 
Moriarty, J, \& Murray, J, (2007), Who Wants to be a Social Worker? Using Routine Published Data to Identify Trends in the Numbers of People Applying for and Completing Social Work Programmes in England, British Journal of Social Work, 37, 4, 715-733

National Council for Voluntary Organisations, (NCVO), (2015), UK Civil Society 2015: Workforce, http://data.ncvo.org.uk/a/almanac15/workforce/

Narey, M, (2014), Making the education of social workers consistently effective. Report of Sir Martin Narey's independent review of the education of children's social workers,

https://www.gov.uk/government/publications/making-the-education-of-social-workersconsistently-effective

Parker, J, \& Bradley, G, (2014), $4^{\text {th }}$ edition, Social Work Practice, London: Sage

Paton, M, (12.11.13), Michael Gove: many social workers 'not up to the job',The Telegraph , http://www.telegraph.co.uk/news/uknews/10442309/Michael-Gove-many-social-workers-not-upto-the-job.html

Research in Practice, (2015), Social work recruitment and retention: strategic briefing, https://www.rip.org.uk

Rogowski, S, (2012), Social Work with Children and Families: Challenges and Possibilities in the Neo-Liberal World, British Journal of Social Work, 42, 921-940.

Scholar H, McLaughlin, H, McCaughan, S, \& Coleman, A, (2014), Learning to Be a Social Worker in a Non-traditional Placement: Critical Reflections on Social Work, Professional Identity and Social Work Education in England, Social Work Education: the international journal, 33,8, 998-1016 Schraer, R, (10.11.2015), Trowler sets out accreditation test for children's social workers, Community Care http://www.communitycare.co.uk/2015/11/10/trowler-sets-accreditation-testchildrens-social-workers/

Skills for Care, (2015), Social work education in England 2009-2014: A report for the Department of Health, http://www.skillsforcare.org.uk/Document-library/NMDS-SC,-workforce-intelligence-andinnovation/NMDS-SC/Social-Work-Education-in-England-FINAL1.pdf

Smith, R, McLenachan, J, Venn, L, Veich, H, \& Anthony ,D, (2013), Step up to Social Work

Programme Evaluation 2012: The Regional Partnerships and Employers Perspectives Research Report, London: Department for Education,

https://www.gov.uk/government/uploads/system/uploads/attachment data/file/205617/DFERR290.pdf

Social Work Reform Board, (2010), Building a safe and confident future: One year on: Detailed proposals from the Social Work Reform Board, 
https://www.gov.uk/government/publications/building-a-safe-and-confident-future-detailedproposals-from-the-social-work-reform-board

Social Work Task Force, (2009), Building a safe, confident future: The final report of the Social Work Task Force, http://www2.warwick.ac.uk/fac/soc/shss/courses

Smith R, McLeneachan, J, Venn, L,, Weich, H, \& Anthony, D, (2013). Step Up to Social Work Programme Evaluation 2012: The Regional Partnerships and Employers Perspectives, London: Department for Education, https://www.gov.uk/government/publications/step-up-to-socialwork-programme-evaluation-2012-the-regional-partnerships-and-employers-perspectives Stevens, M, Moriarty, J, Manthorpe, J, Huseein, S, Sharpe, E, Orme, J, Mclntyre, G, Cavanagh, K, Green-Lister, P, \& Crisp, B, (2012), Helping others or a rewarding career? Investigating student motivations to train as social workers in England, Journal of Social Work, 12, 16-36

The College of Social Work, (n.d.), Roles and Functions of Social Workers in England: Advice Note, http://cdn.basw.co.uk/upload/basw 115640-9.pdf

The College of Social Work, (2012), Reforming social work qualifying education: The social work degree, https://www.basw.co.uk/resource/?id=1160

Wenger, E, (1998), Communities of Practice: Learning, Meaning, and Identity, Cambridge: Cambridge University Press

Wiles, F, (2013), 'Not easily put into a box': constructing professional identity, Social Work Education: the international journal, 32,7,854-866 